\title{
Crecimiento y características de la canal de corderos finalizados con clorhidrato de zilpaterol en pastoreo de alfalfa
}

\section{Growth and carcass characteristics of lambs finished with zilpaterol hydrochloride in grazing alfalfa}

\author{
Ulises Macías Cruza, Leonel Avendaño Reyesa, Ricardo Vicente Péreza, Francisco D. \\ Álvarez Valenzuelaa, Abelardo Correa Calderóna, Humberto González Ríosb, \\ Sergio A. Soto Navarroc, Miguel Melladod
}

\begin{abstract}
RESUMEN
El objetivo del estudio fue evaluar el efecto de clorhidrato de zilpaterol (CZ) sobre la ganancia de peso y las características de la canal en corderos finalizados en pradera de alfalfa y suplementados con concentrado en corral. Un total de 24 corderos machos enteros Dorper x Pelibuey, con peso vivo inicial de $25.0 \pm 0.24 \mathrm{~kg}$, fueron divididos en dos grupos $(n=12)$ y alimentados con 0 o $10 \mathrm{mg} /$ cabeza/día de CZ los últimos 30 días antes del sacrificio. Durante el periodo experimental, todos los corderos pastorearon en alfalfa $8 \mathrm{~h} / \mathrm{d}$ ía y se suplementaron con $450 \mathrm{~g} / \mathrm{d}$ de concentrado. EI CZ no afectó $(P>0.05)$ el peso vivo. Las ganancias de peso diaria y total fueron similares $(P>0.05)$ entre ambos grupos. Las características de canal y el rendimiento de cortes primarios no fueron afectados $(P>0.05$ ) por el CZ. En conclusión, el clorhidrato de zilpaterol a una dosis de $\mathbf{1 0} \mathbf{~ m g / c a b e z a / d i ́ a ~ n o ~ m e j o r o ́ ~ e l ~ c r e c i m i e n t o ~ n i ~}$ las características de canal en corderos finalizados en pradera de alfalfa y suplementados con concentrado.
\end{abstract}

PALABRAS CLAVE: Ovinos de pelo, $\beta$-agonistas adrenérgicos, Zilpaterol, Pastoreo de alfalfa.

\begin{abstract}
The objective of the study was to evaluate the effect of zilpaterol hydrochloride $(\mathrm{ZH})$ on the weight gain and carcass characteristics in lambs finished in alfalfa pasture and supplemented with concentrate in pen. A total of 24 Dorper $x$ Pelibuey ram lambs initially weighting $25.0 \pm 0.24 \mathrm{~kg}$ were divided in two groups $(\mathrm{n}=12)$ and fed with 0 or $10 \mathrm{mg} /$ head/d of $\mathrm{ZH}$ for the last $30 \mathrm{~d}$ before slaughter. During the experimental period, all lambs were grazed in alfalfa during $8 \mathrm{~h} / \mathrm{d}$ and supplemented with $450 \mathrm{~g} / \mathrm{d}$ of concentrate. The ZH did not affect $(P>0.05)$ the live weight. Daily and total weight gains were similar $(P>0.05)$ between both groups. Carcass characteristics and wholesale cut yields were not affected $(P>0.05)$ by $Z$ H. In conclusion, growth and carcass characteristics were not improved by feeding zilpaterol $(10 \mathrm{mg} / \mathrm{head} / \mathrm{d})$ in finished lambs on alfalfa grassland and supplemented with concentrate.
\end{abstract}

KEY WORDS: Hair sheep, $\beta$-adrenergic agonist, Zilpaterol, Grazing alfalfa.

La finalización de corderos bajo sistemas de pastoreo en praderas irrigadas es una estrategia alimenticia que está siendo ampliamente utilizada en diferentes partes del mundo,
Grazing on irrigated pastures for finishing sheep is a feeding strategy that is widely used in different parts of the world, including Mexico, because of the high prices that present both

\footnotetext{
Recibido el 6 de febrero de 2015. Aceptado el 6 de marzo de 2015.

a Universidad Autónoma de Baja California, Instituto de Ciencias Agrícolas, Ejido Nuevo León S/N, 21705 Mexicali, BC., México. Tel. (686) 5118155 lar62@hotmail.com. Correspondencia al primer autor.

b Centro de Investigación en Alimentación y Desarrollo A.C., Hermosillo, Sonora, México.

c New Mexico State University, Department of Animal and Range Science, Las Cruces, USA.

d Departamento de Nutrición Animal, Universidad Autónoma Agraria "Antonio Narro", Coahuila, México.
} 
incluyendo México, debido a los elevados precios que presentan tanto los granos de cereales como las oleaginosas en el mercado. En regiones donde se produce alfalfa (Medicago sativa) y la disponibilidad de agua es abundante, es común la siembra de este forraje como monocultivo o combinado con gramíneas para pastorear ovinos(1). La alfalfa se caracteriza por ser un forraje de alto valor nutricional, ya que su digestibilidad y niveles de proteína (18 a $20 \%$ ) son elevados(2). No obstante, la tasa de crecimiento, la eficiencia alimenticia y algunas características de la canal que muestran los corderos finalizados bajo este sistema de pastoreo son inferiores a lo que generalmente se observa en corderos alimentados en corral con dietas a base granos(3).

Algunos estudios recientes sugieren que la adición de clorhidrato de zilpaterol (CZ) en dietas de finalización de corderos engordados en corral, mejora el comportamiento productivo $(4,5)$ y algunas características de canal de importancia económica (peso y rendimiento en canal, área del músculo Longissimus dorsi) $(6,7)$. No obstante, el uso de CZ en corderos finalizados en pastoreo ha sido escasamente estudiado(8), y sobre praderas irrigadas de alfalfa es nula la información disponible. La suplementación con CZ en corderos que pastorean alfalfa podría ser una estrategia para mejorar su comportamiento productivo y las características de la canal. La alfalfa tiene un gran contenido de proteína altamente degradable en rumen $(\sim 25 \%)(2)$, y algunos estudios han reportado que el uso de fuentes de nitrógeno no proteico en la dieta de rumiantes alimentados con $\mathrm{CZ}$, podría potencializar el efecto favorable de este agonista sobre el crecimiento y el rendimiento en canal de ovinos(5) y becerros de engorda(9). Esto considerando que los agonistas, aparte de estimular el desarrollo muscular(10), también estimulan el crecimiento de la población y la actividad microbiana del rumen(9). Por lo tanto, el objetivo del presente estudio fue evaluar el efecto del CZ sobre el crecimiento y las características de la canal de corderos finalizados en una pradera de alfalfa con suplemento. oilseeds and cereal grains on the market. In regions where the alfalfa (Medicago sativa) is produced and the availability of water is abundant, it is common the planting of this forage as a monoculture or mixed with grasses for grazing sheep(1). The alfalfa is characterized as a forage of high nutritional value, since its digestibility and protein levels (18 to $20 \%$ ) are high(2). However, growth rate, feed efficiency and some carcass characteristics in lambs under this grazing system are lower than those usually seen in feedlot lambs with grain-based diets(3).

Some recent studies suggest that addition of zilpaterol hydrochloride $(\mathrm{ZH})$ in finalization diets for feedlot lambs, improves productive performance $(4,5)$ and some carcass characteristics of economic importance (i.e. weight and carcass yield, Longissimus dorsi muscle area)(6,7). However, the use of $\mathrm{ZH}$ in grazing finished lambs has been sparsely studied(8), and the available information is null on irrigated pastures of alfalfa. Supplementation with $\mathrm{ZH}$ in lambs that graze alfalfa could be a strategy to improve their productive performance and carcass characteristics. Alfalfa has a high content of rumen degradable protein $(\sim$ $25 \%)^{(2)}$, and some studies have reported that the use of sources of non-protein nitrogen in the diet of ruminants Fed $\mathrm{ZH}$, could enhance the positive effect of this agonist on the growth and carcass yield of fattening sheep(5) and steers(9). This, considering that the agonists, apart from stimulating the muscle development(10), also stimulate the growth of the population and microbial activity in the rumen(9). Therefore, the objective of the present study was to evaluate the effect of $\mathrm{ZH}$ on the growth and carcass characteristics of lambs finished in an alfalfa pasture with supplementation.

Standards adopted in Mexico for care (NOM051-ZOO-1995) and the humanitarian slaughter of animals (NOM-033-ZOO-1995) were used to handling lambs. The study was conducted from October 28 to December 15, 2011, at the ranch "Galván", located in the Valley of Mexicali, Baja 
Los corderos utilizados se manejaron siguiendo las normas aprobadas en México para el cuidado (NOM-051-ZOO-1995) y el sacrificio humanitario de los animales (NOM-033-ZOO-1995). El estudio se realizó del 28 de octubre al 15 de diciembre del 2011, en el rancho "Galván", localizado en el Valle de Mexicali, Baja California, al noroeste de México ( $32^{\circ} 25^{\prime} \mathrm{N}$ y $115^{\circ} 06^{\prime}$ O). Las condiciones climáticas durante el periodo experimental fueron muy fluctuantes con presencia de lluvia hacia los días finales (44 $\mathrm{mm}$ ). Los promedios de temperatura ambiental, humedad relativa y radiación solar fueron 12.7 ${ }^{\circ} \mathrm{C}\left(1.4\right.$ a $\left.33.8{ }^{\circ} \mathrm{C}\right), 57.7 \%$ (12.5 a $\left.95.3 \%\right)$ y $11.5 \mathrm{~W} / \mathrm{m}^{2}$ (0 a $62.4 \mathrm{~W} / \mathrm{m}^{2}$ respectivamente).

Un grupo de 40 corderos machos enteros de la cruza Dorper x Pelibuey, con una edad promedio 4.5 meses y acostumbrados a pastorear praderas de alfalfa desde el primer mes de edad, fueron vitaminados con $1.0 \mathrm{ml}$ de vitamina A-D-E (Vigantol, Bayer, Ciudad de México, México) y desparasitados con $0.5 \mathrm{ml}$ de invermectina (Invermectin, Sanfer Laboratory, Ciudad de México) 15 días antes de iniciar el experimento (periodo de adaptación). En general, en este periodo, todos los corderos fueron adaptados a pastorear en el horario de 0700 a $1500 \mathrm{~h}$, y el resto del día a permanecer encerrados dentro de un corral $(10 \times 10 \mathrm{~m})$, el cual estaba provisto con sombra y bebederos. Adicionalmente, los corderos se adaptaron a entrar a corraletas individuales, donde consumían $450 \mathrm{~g} /$ día/cabeza de suplemento divididos en mañana y tarde, y así, garantizar el $100 \%$ del consumo del mismo. El suplemento se formuló con $83 \%$ de trigo molido, $10 \%$ de harina de soya, $5 \%$ de melaza, $0.5 \%$ de ortofosfato, $0.3 \%$ de fosfato dicálcico y $1 \%$ de sal común (Cuadro 1 ).

Después del periodo de adaptación, todos los corderos se pesaron individualmente y se seleccionaron 24 animales de similar peso vivo (PV) y nivel de adaptación al suplemento. Se consideró que un cordero estaba adaptado al proceso de suplementación porque entraba con facilidad a la corraleta individual y consumía
California, Northwest of Mexico (32 $25^{\prime} \mathrm{N}$ and $\left.115^{\circ} 06^{\prime} \mathrm{W}\right)$. Weather conditions during the experimental period were very fluctuating with the presence of rainwater into the final days (44 mm). The averages for temperature, relative humidity and solar radiation were $12.7^{\circ} \mathrm{C}(1.4$ to $\left.33.8^{\circ} \mathrm{C}\right), 57.7 \%(12.5$ to $95.3 \%)$ and 11.5 $\mathrm{W} / \mathrm{m}^{2}$ (0 to $62.4 \mathrm{~W} / \mathrm{m}^{2}$ respectively.

The experiment was developed using 40 Dorper $x$ Pelibuey entire male lambs, with an average age of 4.5 mo accustomed to grazing pastures of alfalfa since the first month of age. They were injected with $1.0 \mathrm{ml}$ of vitamin A-D-E (Vigantol, Bayer, of Mexico City, Mexico) and treated with $0.5 \mathrm{ml}$ of invermectin (Invermectin, Sanfer Laboratory, city of Mexico) $15 \mathrm{~d}$ before the experiment (adaptation period). In general, in this period, all lambs were adapted to grazing on the schedule from 0700 to $1500 \mathrm{~h}$, and the rest of the day to remain in a pen $(10 \times 10 \mathrm{~m})$, provided with shade and drinking. Additionally, lambs were adapted into individual pens, where they consumed $450 \mathrm{~g} / \mathrm{head} / \mathrm{d}$ of supplement divided into morning and afternoon, and thus, ensure a $100 \%$ intake. The supplement was formulated with contained $83 \%$ ground wheat, $10 \%$ soybean meal, $5 \%$ molasses, $0.5 \%$ orthophosphate, $0.3 \%$ dicalcium phosphate and $1 \%$ common salt (Table 1 ).

After the adaptation period, individual weight of all the lambs was recorded to select 24 animals of similar body weight (BW) and adaptation level to the supplement. A lamb that come easily to the individual pen and consumed $100 \%$ of the supplement without any problem of diarrhea was considered adapted to the process of supplementation.

Selected lambs $(B W=25.0 \pm 0.24 \mathrm{~kg}$ and age $=$ $5 \mathrm{mo}$ ) were assigned to 1 of 2 treatments ( $\mathrm{n}=$ 12) under a randomized complete block design, where blocking factor was the initial BW. The treatments consisted in offering $450 \mathrm{~g} / \mathrm{head} / \mathrm{d}$ of supplement mixed with 0 (control) or 10 $\mathrm{mg} / \mathrm{d} /$ head of ZH (Zilmax, Intervet Mexico, DF, Mexico) during $30 \mathrm{~d}$. To ensure the $\mathrm{ZH}$ intake 
$100 \%$ del suplemento sin presentar ningún problema de diarrea.

Los corderos seleccionados $(\mathrm{PV}=25.0 \pm 0.24$ $\mathrm{kg}$ y edad $=5$ meses) se asignaron a 1 de 2 tratamientos $(n=12)$ bajo un diseño de bloques completamente al azar, donde el factor bloqueador fue el PV inicial. Los tratamientos consistieron en ofrecer $450 \mathrm{~g} / \mathrm{día} /$ cabeza de suplemento mezclado con 0 (testigo) o $10 \mathrm{mg} /$ día/cabeza de CZ (Zilmax, Intervet México, DF, México) durante 30 días. Para garantizar el consumo del $\mathrm{CZ}$ en el grupo correspondiente, se mezclaron $75 \mathrm{~g}$ del producto comercial Zilmax con 10,725 g de concentrado; y $30 \mathrm{~g} / \mathrm{día} /$ cordero de esta mezcla se ofreció por la mañana e inmediatamente después de haberlo consumido, se dio el resto de concentrado correspondiente a la mañana. Cabe mencionar que los corderos se introdujeron en corraletas individuales mientras consumían el suplemento. En general, los corderos se alimentaron con $60 \%$ del suplemento antes y $40 \%$ después del pastoreo. En el caso del grupo suplementado con $\mathrm{CZ}$, el agonista se retiró dos días antes de finalizar la prueba. La disponibilidad de agua fue a libre acceso. El peso vivo individual de los corderos se registró al inicio, mitad y final de la prueba de comportamiento. Con esta información se calculó la ganancia de peso diaria y total en el periodo de evaluación.

Se utilizó una pradera de alfalfa que tenía 1.5 años de establecida y una producción de materia seca (MS) de 2,569 kg/ha, considerando $5 \mathrm{~cm}$ de remanente. Antes de iniciar el experimento, se calculó el consumo de materia seca (MS) que tendría el grupo de corderos durante los 30 días, basándose en un consumo diario por animal de $4.5 \%$ de su PV. Así, se determinó que el requerimiento de alfalfa para alimentar los corderos durante todo el periodo experimental era de alrededor de $931.5 \mathrm{~kg}$ de MS. A partir de esta información se delimitaron con malla borreguera tres potreros de 1,209 $\mathrm{m}^{2}(310.6 \mathrm{~kg}$ con remanente de $5 \mathrm{~cm}$ ) cada uno, considerando un periodo de ocupación de 10 días por potrero. Para garantizar que los
Cuadro 1. Composición del suplemento y la alfalfa pastoreada por los ovinos

Table 1. Composition of the supplement and alfalfa grazed by sheep

\begin{tabular}{lcc}
\hline Chemical composition & & Supplement \\
& & Alfalfa \\
\hline Organic matter, \% & 91.5 & 92.0 \\
Crude protein, \% & 15.3 & 17.8 \\
Neutral detergent fiber, \% & 16.5 & 27.1 \\
Acid detergent fiber, \% & 4.7 & 17.8 \\
Hemicelulose, \% & 11.8 & 9.3 \\
Ash, \% & 6.6 & 8.0 \\
ME, Mcal/kg of DM & 3.1 & 2.6 \\
\hline
\end{tabular}

1 Dry base.

2 Offered ingredients: $83.0 \%$ ground wheat, $10.0 \%$ soybean meal, $5.0 \%$ molasses, $0.5 \%$ orthophosphate, $0.3 \%$ dicalcium phosphate and $1.0 \%$ salt.

in the corresponding group, $75 \mathrm{~g}$ of the Zilmax commercial product was mixed with $10,725 \mathrm{~g}$ of concentrate; $30 \mathrm{~g} / \mathrm{d} / \mathrm{lamb}$ of this mixture was offered in the morning and the remainder concentrate was given immediately, corresponding to the morning feeding. It is noteworthy that lambs were introduced in individual pens while taking the supplement. In general, the lambs were fed $60 \%$ of the supplement before and $40 \%$ after pasture. In the case of the group supplemented with $\mathrm{ZH}$, the agonist was withdrawn two days before the end of the test. Water was offered ad libitum. The individual BW of lambs at the beginning, middle and end of the experimental period was recorded to calculate daily and total weight gain.

Alfalfa pasture was $1.5 \mathrm{yr}$ of established and a dry matter production (DM) of $2,569 \mathrm{~kg} / \mathrm{ha}$ considering $5 \mathrm{~cm}$ of remnants. Before starting the experiment, DM intake that would have the group of lambs during the $30 \mathrm{~d}$ it was calculated considering a daily intake per animal of $4.5 \%$ of their BW. Thus, $931.5 \mathrm{~kg}$ of DM was determined to be the requirement of alfalfa to feed the lambs throughout the experimental period. Based on this information, three paddocks of 1,209 $\mathrm{m}^{2}$ were delimited with sheep 
tres potreros se encontraran en el mismo estado fenológico (iniciando la floración) al momento de comenzar el pastoreo, cada potrero se regó y fertilizó (6 kg de urea) 35 y 10 días antes de ingresar los corderos a pastorear.

Muestras de alfalfa y de suplemento se colectaron semanalmente en bolsas de papel para ser llevadas al laboratorio de nutrición del Instituto de Ciencias Agrícolas (ICA), de la Universidad Autónoma de Baja California (UABC), donde se secaron en una estufa de aire forzado a $60{ }^{\circ} \mathrm{C}$ durante $48 \mathrm{~h}, \mathrm{y}$ almacenadas para su posterior análisis bromatológico con la metodología $\mathrm{AOAC(11)}$ y Van Soest et a(12). La cantidad de nutrientes digestible totales(13) y de energía digestible $(E D)(14)$ se calcularon con el objeto de poder conocer la energía metabolizable (EM) de acuerdo con el NRC(14).

Finalizada la prueba en pradera, todos los corderos se ayunaron $12 \mathrm{~h}$ y se sacrificaron por el método de degüelle en el Laboratorio de Carnes del ICA-UABC. La sangre se colectó en bolsas de plástico para registrar su peso. Asimismo, piel, cabeza, patas, testículos, grasa pélvica-renal-corazón $(\mathrm{KPH})$ y órganos viscerales (corazón, pulmones, hígado, riñones, bazo, rumen e intestino delgado) se removieron del cuerpo del animal para registrar sus pesos, así como el peso de la canal caliente (PCC). Posteriormente, las canales se refrigeraron a 4 ${ }^{\circ} \mathrm{C}$ por $24 \mathrm{~h}$ para registrar las siguientes características: peso de la canal fría (PCF), longitud de la canal, profundidad del tórax, longitud y perímetro de la pierna, área del músculo Longissimus dorsi (MLD) y espesor de grasa dorsal(4). Entre la $12^{\mathrm{a}}$ y $13^{\mathrm{a}}$ costilla, las canales se cortaron transversalmente para medir el área del MLD con una cuadricula de puntos $(64 \mathrm{~mm})$, así como el espesor de la grasa dorsal con un vernier. Cabe mencionar, que una persona entró al cuarto frío a los 45 min y 24 $\mathrm{h}$ post mortem para medir el pH del MLD utilizando un potenciómetro portátil que estaba provisto de un electrodo de penetración (Hanna mesh ( $310.6 \mathrm{~kg}$ with remnants of $5 \mathrm{~cm}$ ) each, considering an occupation period of $10 \mathrm{~d}$ per paddock. To ensure that the three paddocks were in the same phenological state (beginning bloom) at the time of start grazing, each pasture was watered and fertilized (6 $\mathrm{kg}$ of urea) at d 35 and 10 before joining the lambs to graze.

Alfalfa and supplement samples collected weekly in paper bags were taken to the Nutrition laboratory of the Instituto de Ciencias Agricolas (ICA), of the Universidad Autonomous de Baja California (UABC). They were dried in a forced air oven at $60^{\circ} \mathrm{C}$ for $48 \mathrm{~h}$, and stored for later bromatological analysis by the AOAC methodology(11) and Van Soest et a/12). The amounts of total digestible nutrients(13) and digestible energy $(D E)(14)$ were calculated in order to know the metabolizable energy (ME) according to NRC(14).

After the grazing test, all lambs were fasted $12 \mathrm{~h}$ and slaughtered by the disgorgement method in the ICA-UABC meat laboratory. The blood was collected in plastic bags and weighted. In addition, skin, head, foot, testicles and pelvic-renal-heart $(\mathrm{KPH})$ fat and visceral organs (heart, lungs, liver, kidneys, spleen, rumen and small intestine) were removed from the body to register their weights, as well as the hot carcass weight (HCW). Subsequently, the carcass were chilled at $4{ }^{\circ} \mathrm{C}$ for $24 \mathrm{~h}$ to register the following features: cold carcass weight (CCW), carcass length, thorax depth, leg length and perimeter, Longissimus dorsi muscle area (LDM) and fat thickness(4). Between the $12^{\text {th }}$ and $13^{\text {th }}$ rib, carcasses were transversely cut to measure with a grid point $(64 \mathrm{~mm})$ the LDM area, as well as the fat thickness with a vernier scale. It is worth mentioning, that a person entered in the cold room at $45 \mathrm{~min}$ and $24 \mathrm{~h}$ post-mortem to measure $\mathrm{pH}$ of the LDM using a portable potentiometer, which was equipped with a penetration electrode (Hanna Instruments, model HI 98140, Woonsocket, RI, USA). Finally, carcasses were divided into wholesale cuts(4). 
Instruments, model HI 98140, Woonsocket, RI, USA). Finalmente, las canales se dividieron en cortes primarios(4). El cuarto delantero a su vez se dividió en cuello, costillas, lomo y paleta, mientras que el cuarto trasero en piernas, lomo plano y faldilla del lomo. En el caso de los pesos de cortes primarios y de grasa KPH se expresaron como porcentaje del PCC. Los pesos de canal caliente y los órganos viscerales se expresaron como porcentaje del peso al sacrificio.

Todas las variables de estudio se sometieron a un análisis de varianza bajo un diseño de bloques completos al azar utilizando el procedimiento GLM del programa estadístico SAS(15). Las comparaciones entre medias se realizaron con la prueba de t-student a una $\alpha=$ 0.05 .

El crecimiento de los corderos en la pradera de alfalfa no se afectó $(P>0.05)$ por la suplementación con CZ (Cuadro 2), observándose que en promedio ambos grupos tuvieron un incremento de peso de $5.4 \pm 0.5$ $\mathrm{kg}$ después de los 30 días de prueba. En forma similar, en corderos Pelibuey enteros finalizados por 30 días en praderas de zacate Dichantium aristatum, no se reportó efecto de suplementación de $10 \mathrm{mg}$ de $\mathrm{CZ}$ sobre la ganancia de peso total y diaria(8). En corderos engordados en corral con dietas formuladas con
The forequarter was divided into neck, ribs, loin and shoulder, while the hindquarter on legs, plain loin and the back skirt. Weights of wholesale cuts and $\mathrm{KPH}$ fat were expressed as a percentage of HCW. Hot carcass weights and visceral organs were expressed as a percentage of the slaughter weight.

All variables were subjected to a variance analysis under a randomized complete block design using the GLM procedure of the SAS statistical software(15). Comparisons between means were performed with t-student test to a $\alpha=0.05$.

The growth of lambs in the alfalfa pasture was not affected $(P>0.05)$ by supplementation with $\mathrm{ZH}$ (Table 2), noting that, on average, both groups had a weight increase of $5.4 \pm 0.5 \mathrm{~kg}$ after the 30-d trial. Similarly, in Pelibuey lambs finished by $30 \mathrm{~d}$ in Dichantium aristatum grass, dietary supplementation of $10 \mathrm{mg} / \mathrm{head} / \mathrm{d}$ of $\mathrm{ZH}$ did not increase total and daily weight gain(8). Some studies also found evidence that in lambs fattened in feedlots with grain-diets, $6.7 \mathrm{mg}(16)$ or $10 \mathrm{mg}(17)$ of $\mathrm{ZH}$ did not improve growth; however, some research on lambs in pen indicates a positive effect of this $\beta$-agonist on the final BW, weight gain and feed efficiency, without altering DM intake $(5,18,19)$. Therefore, these results suggest that zilpaterol may improve the growth of the hair sheep breeds, only when

Cuadro 2. Crecimiento de ovinos en pastoreo de alfalfa y suplementados con clorhidrato de zilpaterol

Table 2. Growth of sheep grazing alfalfa and supplemented with zilpaterol hydrochloride

\begin{tabular}{lccc}
\hline & \multicolumn{2}{c}{ Zilpaterol hydrochloride $(\mathrm{mg} / \mathrm{head} / \mathrm{d})$} & \\
\cline { 2 - 3 } Variables & 0 & 10 & $\mathrm{SE}$ \\
\hline Initial weight, $\mathrm{kg}$ & 25.0 & 25.1 & 0.1 \\
Final weight, $\mathrm{kg}$ & 30.8 & 30.4 & 0.5 \\
Total weight gain, $\mathrm{kg}$ & 5.8 & 5.3 & 0.5 \\
Daily weight gain, g/d & 194.0 & 177.0 & 30.0 \\
\hline SE= Standard error. & & & \\
$(P>0.05)$. & & &
\end{tabular}


base en grano, algunos estudios tampoco encontraron evidencia de que $6.7(16)$ o $10(17)$ mg de CZ mejoraran el crecimiento; no obstante, algunas investigaciones sobre corderos finalizados en corral indican un efecto positivo de este $\beta$-agonista sobre el peso final, la ganancia de peso y la eficiencia alimenticia, sin alterarse el consumo de $\mathrm{MS}(5,18,19)$. Por lo tanto, estos resultados sugieren que el zilpaterol puede mejorar el crecimiento de los corderos de razas de pelo, solamente cuando son finalizados en corral con dietas ricas en granos, pero no bajo condiciones de pastoreo.

Las características de la canal (Cuadro 3) y los rendimientos de cortes primarios (Cuadro 4) fueron similares $(P>0.05)$ entre corderos alimentados con o sin CZ. No se encontraron estudios que hayan evaluado las características de la canal y los cortes primarios en corderos suplementados con $\mathrm{CZ}$ bajo condiciones de

Cuadro 3. Características de la canal de ovinos en pastoreo de alfalfa y suplementados con clorhidrato de zilpaterol

Table 3. Carcass traits of sheep grazing alfalfa and supplemented with zilpaterol hydrochloride

\begin{tabular}{|c|c|c|c|}
\hline \multirow[b]{2}{*}{ Variable } & \multicolumn{2}{|c|}{$\begin{array}{l}\text { Zilpaterol hydrochloride } \\
\qquad(\mathrm{mg} / \mathrm{head} / \mathrm{d})\end{array}$} & \multirow[b]{2}{*}{ SE } \\
\hline & 0 & 10 & \\
\hline Hot carcass weight, kg & 13.3 & 13.8 & 0.4 \\
\hline Cold caracass weight, kg & 13.2 & 13.7 & 0.4 \\
\hline Dressing, $\%$ & 44.6 & 45.2 & 2.5 \\
\hline KPH fat, \% & 0.6 & 0.4 & 0.1 \\
\hline Fat thickness, cm & 0.7 & 0.9 & 0.5 \\
\hline Carcass lenght, $\mathrm{cm}$ & 57.7 & 56.9 & 1.2 \\
\hline Longissimus dorsi area, $\mathrm{cm}^{2}$ & 14.8 & 15.2 & 0.9 \\
\hline Thorax depth, $\mathrm{cm}$ & 15.9 & 14.9 & 0.6 \\
\hline Leg lenght, cm & 27.7 & 27.7 & 0.9 \\
\hline Leg perimeter, $\mathrm{cm}$ & 38.3 & 39.4 & 1.0 \\
\hline Post-mortem pH at $45 \mathrm{~min}$ & 6.8 & 6.7 & 0.1 \\
\hline Post-mortem pH at $24 \mathrm{~h}$ & 6.2 & 6.1 & 0.2 \\
\hline
\end{tabular}

$\mathrm{SE}=$ Standard error.

$\mathrm{KPH}=$ kidney-heart-pelvic fat.

they are finished in pens with diets rich in grains, but not under grazing conditions.

Carcass characteristics (Table 3) and wholesale cut yields (Table 4$)$ were similar $(P>0.05)$ between lambs fed with or without $\mathrm{ZH}$. No studies were found that evaluated these characteristics in lambs supplemented with $\mathrm{ZH}$ under grazing conditions. However, the results of this research are contrary to expectations, since most of the works done in finishing feedlot lambs found a positive effect of zilpaterol (variable doses of 6.7 to $17.5 \mathrm{mg} / \mathrm{head} / \mathrm{d}$ ) on carcass characteristics $(16,17,19)$ and wholesale cut yields $(4,7,17)$ of economic importance (HCW, CCW, dressing percentage, LDM area, and percentage of ribs and legs).

Possibly, the lack of effect of zilpaterol on growth, carcass characteristics and wholesale cut yields, was due to failures in the body transport of $\mathrm{ZH}$ molecules, or to negative changes in the $\beta_{2}$-adrenergic receptor at striated muscle level due to environmental factors (temperature, exposure to direct sunlight, high

Cuadro 4. Rendimiento de cortes primarios de ovinos en pastoreo de alfalfa y suplementados con clorhidrato de zilpaterol $(\%)^{*}$

Table 4. Wholesale cut yields of sheep grazing alfalfa and supplemented with zilpaterol hydrochloride $(\%)^{*}$

\begin{tabular}{lccc}
\hline & \multicolumn{3}{c}{$\begin{array}{c}\text { Zilpaterol hydrochloride } \\
\text { (mg/head/d) }\end{array}$} \\
\cline { 2 - 3 } Variable & 0 & 10 & SE \\
\hline Forequarter & 59.8 & 59.4 & 0.8 \\
$\quad$ Neck & 4.6 & 4.8 & 0.5 \\
Ribs & 19.8 & 20.3 & 0.9 \\
Loin & 10.5 & 10.8 & 0.3 \\
Shoulder & 24.8 & 23.5 & 1.8 \\
Hindquarter & 40.2 & 41.6 & 0.8 \\
Leg & 19.9 & 20.6 & 0.6 \\
Plane loin & 9.5 & 10.0 & 0.3 \\
Back skirt & 10.9 & 11.2 & 6.1 \\
\hline SE= Standard error. & \multicolumn{3}{l}{} \\
* Expressed as a percentage of hot carcass weight. \\
(P>0.05).
\end{tabular}


pastoreo. Sin embargo, los resultados de esta investigación son contrarios a lo esperado, ya que la mayoría de los trabajos donde finalizaron los corderos en corral han encontrado un efecto positivo de zilpaterol (dosis variables 6.7 a 17.5 $\mathrm{mg} / \mathrm{cabeza} /$ día) sobre rasgos en canal $(16,17,19)$ y cortes primarios $(4,7,17)$ de importancia económica (PCC, PCF, rendimiento en canal, área del MLD, y porcentaje de costillas y piernas).

Posiblemente, la ausencia de efecto de zilpaterol sobre crecimiento, características de la canal y rendimiento de cortes primarios en corderos engordados en pradera irrigada de alfalfa, se deba a fallas en el transporte corporal de las moléculas del $\mathrm{CZ}$ o alteraciones negativas en los receptores adrenérgicos $\beta_{2}$ a nivel de músculo estriado, por efecto de factores ambientales (temperatura, exposición a radiación solar directa, alta actividad motora, estrés por depredadores, otros) $(6,10)$. Así, el acoplamiento entre moléculas de $\mathrm{CZ}$ y receptores no se dio de manera correcta, provocando que dicho agonista $\beta_{2}$ no promoviera la síntesis de proteína y evitara la proteólisis a nivel de músculo; asimismo, redujera la lipogénesis e incrementara la lipólisis en tejido graso(20). Esta situación conllevó a que CZ no incrementara la formación de masa muscular en regiones corporales como piernas y lomos, lo cual se reflejó en un nulo efecto de dicho agonista sobre la ganancia de peso, PCC, rendimiento en canal, área del MLD, grasa corporal, rendimiento de cortes primarios, y otros. Se menciona que el mecanismo de acción in vivo de los receptores $\beta$, es extremadamente sensible a otros eventos secundarios que causen respuestas endocrinas o fisiológicas en el tejido donde se encuentran(10).

La administración de $\mathrm{CZ}$ redujo $(P<0.05)$ el porcentaje de sangre, piel y corazón en los corderos, sin efecto ( $P>0.05)$ del agonista sobre el porcentaje de otros órganos viscerales (Cuadro 5). El porcentaje de hígado tendió a disminuir $(P=0.08)$ por efecto de CZ. Los resultados publicados en relación al efecto de activity, stress by predators, other) $(6,10)$. Thus, coupling between molecules of $\mathrm{ZH}$ and receptors did not occur properly, causing that the $\beta_{2^{-}}$ agonist did not promote protein synthesis and avoid proteolysis at muscle level, and also, it would reduce lipogenesis and increased lipolysis in fat tissue(20). This situation did not allow the $\mathrm{ZH}$ increase muscle mass formation in parts of the body such as legs and loin, which was reflected in a null effect of this agonist on the weight gain, HCW, dressing percentage, LDM area, body fat, wholesale cut yields, others. Reports show that the mechanism of action in vivo of $\beta_{2}$ receptors is extremely sensitive to other secondary events that cause endocrine or physiological responses within the target tissue(10).

Administration of $\mathrm{ZH}$ reduced $(P<0.05)$ the percentage of blood, skin and heart in the lambs, without effect $(P>0.05)$ on the percentage of other visceral organs (Table 5). The percentage of liver tended to decrease $(P=0.08)$ by effect of $\mathrm{ZH}$. Results published in relation to the effect of zilpaterol on the development of visceral organs are contradictory. So far, no studies had reported a reduction in the percentage of blood, skin and heart by feeding $\mathrm{ZH}$ in lambs. Some researchers(17) reported only an increase in the percentage of peritoneum and head by addition of $10 \mathrm{mg} /$ head/d of zilpaterol; although subsequently other authors(4) determined a contrary effect on these same components of the body using the same dose. Meanwhile, in other study(21) indicated that administration of $7.4 \mathrm{mg} / \mathrm{head} / \mathrm{d}$ only reduced the percentage of rumen, liver and visceral fat. It is noteworthy that by using other $\beta$-agonists such as L-644, 969(22), reported a reduction in the weight of heart and liver in lambs. Possibly, the reduction in the weights of those organs is due to greater wear and tear, as a result of an increase in the metabolic activity by the action of $\beta$-agonists, which would explain the decrease in the percentage of heart weight in the present study. Recently, it was reported a reduction in the skin weight of goats when they were 
zilpaterol sobre el desarrollo de órganos viscerales son contradictorios. Hasta el momento ningún estudio había reportado una reducción en el porcentaje de sangre, piel y corazón por alimentar los corderos con CZ. Algunos investigadores(17) reportaron solamente un aumento en el porcentaje de peritoneo y cabeza por acción de adicionar $10 \mathrm{mg}$ de zilpaterol, aunque posteriormente otros autores(4) determinaron un efecto contrario sobre estos mismos componentes del cuerpo usando la misma dosis. Por su parte, un grupo de investigación(21) indicó que la administración de $7.4 \mathrm{mg}$ solamente redujo el porcentaje del rumen, hígado y grasa visceral. Cabe mencionar que usando otros $\beta$-agonistas tales como el $\mathrm{L}-644,969(22)$, se reportó una reducción en el peso del corazón e hígado en corderos. Posiblemente, la reducción en los pesos de esos órganos se deba a un mayor desgaste como consecuencia de un incremento en la actividad metabólica por acción de los agonistas $\beta$, lo cual explicaría la disminución del porcentaje en el corazón en el presente estudio. Recientemente, se reportó una reducción en el peso de la piel de cabras cuando se suplementaron con $\mathrm{CZ}$ durante 42 días en corral(23), lo cual coincide con lo observado en este reporte.

Se concluye que el $\mathrm{CZ}$ a una dosis de $10 \mathrm{mg} /$ cabeza/día no altera el crecimiento ni las características de canal en corderos enteros engordados en pradera de alfalfa y con suplemento alimenticio. Sin embargo, bajo estas condiciones de alimentación, aparentemente el $\mathrm{CZ}$ reduce la cantidad de sangre circulante y el peso del corazón. En general, los resultados del presente estudio sugieren no suplementar con CZ a corderos engordados durante la etapa de finalización bajo condiciones de pastoreo, al menos en praderas de alfalfa.

\section{LITERATURA CITADA}

1. Mendiola GA, Martínez HPA, Cortés DE, Sánchez DRC. Efecto del pastoreo mixto y monoespecífico en una pradera de Alfalfa-Ovillo. Agrociencia 2007;41(1):395-403.
Cuadro 5. Porcentaje de cabeza, sangre, piel y órganos viscerales de ovinos en pastoreo de alfalfa y suplementados con clorhidrato de zilpaterol ${ }^{\star}$

Table 5. Percentage of head, blood, skin and visceral organs of sheep grazing alfalfa and supplemented with zilpaterol hydrochloride*

\begin{tabular}{lccc}
\hline & \multicolumn{3}{c}{$\begin{array}{c}\text { Zilpaterol hydrochloride } \\
(\mathrm{mg} / \mathrm{head} / \mathrm{d})\end{array}$} \\
\cline { 2 - 3 } & 0 & 10 & SE \\
\hline Head & 6.9 & 6.5 & 0.3 \\
Blood & $4.8^{\mathrm{a}}$ & $4.2^{\mathrm{b}}$ & 0.1 \\
Skin & $9.2^{\mathrm{a}}$ & $8.0^{\mathrm{b}}$ & 0.1 \\
Heart & $0.6^{\mathrm{a}}$ & $0.4^{\mathrm{b}}$ & 0.0 \\
Lungs & 1.7 & 1.9 & 0.2 \\
Liver & 1.9 & 1.7 & 0.1 \\
Kidneys & 0.4 & 0.4 & 0.1 \\
Spleen & 0.2 & 0.2 & 0.1 \\
Rumen & 3.9 & 2.9 & 0.3 \\
Small intestine & 3.3 & 3.1 & 0.2 \\
\hline
\end{tabular}

* Expressed as percentage of the salughter weight.

$\mathrm{SE}=$ Standard error.

ab Values with distinct superscript are different $(P<0.05)$.

supplemented in pen with ZH for $42 \mathrm{~d}(23)$, which coincides with results from this report.

In conclusion, the $\mathrm{ZH}$ at a dose of $10 \mathrm{mg} /$ head/d does not alter the growth and carcass characteristics in entire male lambs fattened in alfalfa pasture plus nutritional supplement. However, under these conditions, apparently the $\mathrm{ZH}$ reduces the amount of circulating blood and the weight of the heart. In general, results of this study suggest not supplement with zilpaterol hydrochloride to lambs fattened during the finishing stage under grazing conditions, at least in alfalfa grasslands.

End of english version

2. Bhatti SA, Bowman JGP, Firkins JL, Grove AV, Hunt CV. Effect of intake level and alfalfa substitution for grass hay on ruminal kinetics of fiber digestion and particle passage in beef cattle. J Anim Sci 2008;86(1):34-145. 
Ulises Macías Cruz, et al. / Rev Mex Cienc Pecu 2016;7(2):243-252

3. McClure KE, Van KRW, Althouse PG. Performance and carcass characteristics of weaned lambs either grazed on orchardgrass, ryegrass, or alfalfa or fed all-concentrate diets in drylot. J Anim Sci 1994;72(12):3230-3237.

4. Avendaño RL, Macías CU, Álvarez VFD, Águila TE, Torrentera ONG, Soto NSA. Effects of zilpaterol hydrochloride on growth performance, carcass characteristics, and wholesale cut yield of hair-breed ewe lambs consuming feedlot diets under moderate environmental conditions. J Anim Sci 2011;89(12):4188-4194.

5. Macías CU, Álvarez VFD, Soto NSA, Águila TE, Avendaño RL. Effect of zilpaterol hydrochloride on feedlot performance, nutrient intake, and digestibility in hair-breed sheep. J Anim Sci 2013;91(4):1844-1849.

6. Macías CU, Avendaño RL, Álvarez VFD, Torrentera ONG, Meza HCA, Mellado BM, et al. Crecimiento y características de canal en corderas tratadas con clorhidrato de zilpaterol durante primavera y verano. Rev Mex Cienc Pecu 2013;4(1):1-12.

7. Dávila RJL, Macías CU, Torrentera ONG, González RH, Soto NSA, Rojo RR, et al. Effects of zilpaterol hydrochloride and soybean oil supplementation on carcass characteristics of hair-breed ram lambs under heat stress conditions. J Anim Sci 2014;92(3):1184-1192.

8. Salinas CJ, Domínguez MM, Díaz MR, Cruz BP, Montaño GMF, Arzola ÁC. Effect of duration of zilpaterol hydrochloride treatment on carcass characteristics and weight gain in grazing Pelibuey lambs. J Appl Anim Res 2006;29(1)25-28.

9. Walker CE, Drouillard JS. Effects of ractopamine hydrochloride are not confined to mammalian tissue: Evidence for direct effects of ractopamine hydrochloride supplementation on fermentation by ruminal microorganisms. J Anim Sci 2010;88(2):697-706.

10. Mersmann $\mathrm{HJ}$. Overview of the effects of beta-adrenergic receptor agonists on animal growth including mechanisms of action. J Anim Sci 1998;76(1):160-172.

11. AOAC. Official methods of analysis, $15^{\text {th }}$ ed. Association of Official Analytical Chemists. Arlington, VA, USA. 1990

12. Van SPJ, Robertson PJ, Lewis BA. Methods for dietary fiber, neutral detergent fiber, and non-starch polysaccharides in relation to animal nutrition. J Dairy Sci 1991;74(10):223232.

13. Cappelle ER, Filho SCV, Da Silva JFC, Cecon PR. Estimativas do valor energético a partir de características químicas e bromatológicas dos alimentos. Rev Bras Zootec 2001;30(6):1837-1856.

14. NRC. Nutrient requirements of sheep. National Academy Press, Washington, DC. 1985.

15. SAS INSTITUTE, SAS/STAT: User's guide statistics released 9.1, 2nd Ed. SAS Institute, Inc. Cary, NC, USA. 2004.

16. López CMA, Ramírez RG, Aguilera SJI, Arechiga CF, Méndez $\mathrm{LF}$, Rodríguez $\mathrm{H}$, Silva JM. Effect of ractopamine hydrochloride and zilpaterol hydrochloride on growth, diet digestibility, intake and carcass characteristics of feedlot lambs. Livestock Sci 2010;131(1):23-30.

17. Macías CU, Álvarez VFD, Torrentera ONG, Velázquez MV, Correa CA, Avendaño RL. Effect of zilpaterol hydrochloride on feedlot performance and carcass characteristics of ewe lambs during heat-stress conditions. Anim Prod Sci 2010;50(1):983-989.

18. Robles EJC, Barreras SA, Contreras G, Estrada AA, Obregón $\mathrm{JF}$, Plascencia A, Zinn RA. Effect of two $\beta$-adrenergic agonists on finishing performance and carcass characteristics in lambs fed all-concentrate diets. J Appl Anim Res 2009;36(1):3336.

19. Mondragón J, Domínguez VIA, Pinos RJM, González M, Bórquez JL, Domínguez $A$, et al. Effects of feed supplementation of zilpaterol hydrochloride on growth performance and carcass traits of finishing lambs. Acta Agr Scand 2010;60(1):47-52.

20. Dunshea FR, D'Souza DN, Pethick DW, Harper GS, Warner RD. Effects of dietary factors and other metabolic modifiers on quality and nutritional value of meat. Meat Sci 2005;71(1):8-38.

21. Ríos RFG, Barreras SA, Estrada-Angulo A, Obregón JF, Plascencia A, Portillo-Loera JJ, et al. Effect of level of dietary zilpaterol hydrochloride ( $\beta 2$-agonist) on performance, carcass characteristics and visceral organ mass in hair lambs fed all-concentrate diets. J Appl Anim Res 2010;38(1):33-38.

22. Koohmaraie $M$, Shackelford SD, Wheeler TL. Effects of a $\beta$ Adrenergic agonist (L644, 969) and male sex condition on muscle growth and meat quality of callipyge lambs. J Anim Sci 1996;74(1):70-79.

23. López CMA, Aguilera SJI, Ramírez RG, Rodríguez H, Carrillo MO, Méndez LF. Effect of zilpaterol hydrochloride on growth performance and carcass characteristics of wether goats. Small Ruminant Res 2014;117(1):142-150. 